\title{
Novel Borrelia species detected in echidna ticks, Bothriocroton concolor, in Australia
}

\author{
Siew-May Loh', Alexander W. Gofton', Nathan Lo², Amber Gillett ${ }^{3}$, Una M. Ryan', Peter J. Irwin ${ }^{1}$ \\ and Charlotte L. Oskam ${ }^{1 *}$
}

\begin{abstract}
Background: To date, little has been documented about microorganisms harboured within Australian native ticks or their pathogenic potential. Recently, a Borrelia sp. related to the Relapsing Fever (RF) group was identified in a single tick removed from a wild echidna (Tachyglossus aculeatus). The present study investigated the presence of Borrelia in 97 Bothriocroton concolor ticks parasitizing echidnas in Queensland, New South Wales, and Victoria, Australia, using nested PCR with Borrelia-specific primers targeting the 16S rRNA (16S) and flaB genes.

Results: Borrelia-specific PCR assays confirmed the presence of a novel Borrelia sp. related to the RF and reptile-associated (REP) spirochaetes in 38 (39 \%) B. concolor ticks. This novel Borrelia sp. was identified in 41 \% of the B. concolor ticks in Queensland and New South Wales, but not in any ticks from Victoria. The resulting flaB sequences (407 bp) were 88 and $86 \%$ similar to the flaB sequences from Borrelia turcica and Borrelia hermsii, respectively. Of the ticks confirmed as Borrelia-positive following the flaB assay, 28 were positive with the 165 assay. Phylogenetic analysis of the $16 \mathrm{~S}$ sequences (1097 bp) suggests that these sequences belong to a novel Borrelia sp., which forms a unique monophyletic clade that is similar to, but distinct from, RF Borrelia spp. and REP-associated Borrelia spp.

Conclusions: We conclude that the novel Borrelia sp. identified in this study does not belong to the Borrelia burgdorferi (sensu lato) complex, and that the phylogenetic analysis of the partial 165 gene sequences suggests it forms a unique monophyletic cluster in the genus Borrelia, potentially forming a fourth major group in this genus associated with monotremes in Australia. However, a thorough molecular characterisation will be required to confirm the phylogenetic position of this unique Borrelia sp. The zoonotic potential and pathogenic consequences of this novel Borrelia sp. are unknown at the current time.
\end{abstract}

Keywords: Tick-borne disease, Bothriocroton concolor, Borrelia, Echidna, Australia

\section{Background}

Ticks (Acari: Ixodida) transmit the greatest diversity of zoonotic pathogens, including bacteria, protozoa and viruses, of any arthropod and are of major concern to the health and wellbeing of humans, wildlife, livestock and companion animals [1]. Globally, ticks are associated with the transmission of many bacterial pathogens; those of most concern belong predominantly to the genera Anaplasma [2], Borrelia [3], Ehrlichia [4], Francisella [5] and Rickettsia [6]. In Australia, enzootic ticks

\footnotetext{
* Correspondence: c.oskam@murdoch.edu.au

'Vector and Water-Borne Pathogen Research Laboratory, School of Veterinary and Life Sciences, Murdoch University, Perth, Western Australia, Australia Full list of author information is available at the end of the article
}

that parasitise humans and companion animals also serve as hosts for zoonotic pathogens [7].

In Australia, 70 native and introduced tick species have been described, comprising 56 hard ticks (family Ixodidae: genera Amblyomma, Bothriocroton (formerly Aponomma), Haemaphysalis, Ixodes, and Rhipicephalus,) and 14 soft ticks (family Argasidae: genera Argas and Ornithodoros) [8]. Only a few of these ticks are known to transmit pathogens associated with human tick-borne diseases (TBD); currently there are three zoonotic TBDs recognised in Australia associated with native tick species. For example, Rickettsia australis and Rickettsia honei, the causative agents of Queensland tick typhus and Flinders Island Spotted Fever, respectively, are associated with Ixodes holocyclus (Australian paralysis 
tick), Bothriocroton hydrosauri (reptile tick), and Ixodes tasmani (marsupial tick) [9-12]. In addition, Coxiella burnetii, the causative agent of $\mathrm{Q}$ fever, has been detected in Haemaphysalis humerosa, the bandicoot tick [13, 14], and Amblyomma triguttatum, the ornate kangaroo tick [15]. These ticks are thought to play a role in the life-cycle of C. burnetii and this pathogen has been detected in a number of wild animals [16, 17]. Although wildlife are often suggested to be reservoirs for such pathogens in Australia and abroad [16, 18], the importance of wildlife ticks in the ecology of these pathogens is often overlooked or neglected.

Spirochaetes in the genus Borrelia are transmitted by arthropods and are classified traditionally into two groups: Lyme Borreliosis (LB) Borrelia burgdorferi (sensu lato) (s.l.), transmitted by several species of ixodid ticks, and Relapsing Fever (RF) Borrelia, transmitted primarily by argasid ticks (tick-borne RF, TBRF) [19], a few species by ixodid ticks [20-23], and also by lice [24]. The LB group is the most significant from a human health perspective [25]. The LB group consists of 18 species, of which the principal LB-causing agents include Borrelia afzelii, Borrelia burgdorferi (sensu stricto) (s.s.), and Borrelia garinii, which are transmitted by the ticks Ixodes pacificus and Ixodes scapularis in the United States, Ixodes ricinus in Europe, and Ixodes persulcatus in Europe and Asia [25].

The TBRF Borrelia group is conventionally divided geographically into 'Old World' RF organisms such as Borrelia crocidurae, Borrelia duttonii and Borrelia hispanica; and 'New World' RF species such as Borrelia hermsii, Borrelia parkeri and Borrelia turicatae [26, 27]. Although RF Borrelia are predominantly associated with soft ticks, well-known examples of hard ticks-associated TBRF Borrelia include: Borrelia miyamotoi, isolated from I. persulcatus and I. ricinus in Europe and Asia [28-30] and I. scapularis and I. pacificus in north-eastern and western United States, respectively [31, 32]; Borrelia lonestari in Amblyomma americanum [33]; 'Candidatus Borrelia texasensis' in Dermacentor variabilis in the southern states of North America [34]; and Borrelia theileri in Rhipicephalus (Boophilus) microplus [21]. While also recorded in Europe, Asia and North America [35-37], TBRF is a common bacterial infection in several regions in Africa resulting in febrile illness and spirochaetaemia [38-40].

In 2003, a novel Borrelia sp. was isolated from a hard tick, Hyalomma aegyptium, removed from a tortoise in Istanbul, Turkey [41]. This species was later named Borrelia turcica [41, 42] and is genetically distinct from the LB and RF spirochaetes. Further studies have since supported a third major Borrelia group classification, designated the reptile-associated (REP) Borrelia sp. group [43].

In Australia, three borreliae have been reported: $B$. theileri, the causative agent of bovine spirochaetosis worldwide, transmitted by the cattle tick, $R$. (Boophilus) australis [44, 45]; Borrelia anserina associated with poultry and transmitted by the soft tick, Argas persicus [7, 46, 47]; and Borrelia queenslandica from long-haired rats, Rattus villosissimus, in north-west Queensland, which at the time could not be detected within the proposed tick vector, Ornithodoros gurneyi [48]. Spirochaetes have also been observed within blood films of bandicoots, cattle, kangaroo and rodents [49] and in $I$. holocyclus and Haemaphysalis spp. ticks, collected from companion animals and livestock [50].

Echidnas, also known as spiny anteaters, are egglaying mammals classified under the order Monotremata and belonging in the family Tachyglossidae [51]. The short-beaked echidna ( $T$. aculeatus) is found in Australia and New Guinea, and is comprised of five subspecies (ssp.): T. a. acanthion, T. a. aculeatus, T. a. multiaculeatus, and T. a. setosus, can be found exclusively in Australia, while T. a. lawesii is found in New Guinea [51]. In a recent molecular survey of bacteria associated with native Australian humanbiting ticks, a novel Borrelia sp. related to the RF group was identified in a single $I$. holocyclus tick removed from an echidna host [52]. This finding prompted the current investigation to further assess the occurrence and phylogenetic position of Borrelia sp. in ticks collected from echidnas in three regions of Australia and to provide greater insight into its distribution in Australia.

\section{Methods}

\section{Tick sample collection and identification}

A total of 97 ticks were collected from 22 echidnas (T. aculeatus ssp.) by veterinarians at the Australian Zoo Wildlife Hospital in Beerwah, Queensland $(n=$ 81), wildlife carers at the Wild Days Wildlife shelter in Narre Warren, Victoria $(n=4)$, and through public submission from Wagga Wagga, western New South Wales $(n=12)$. Ticks were preserved in $70 \%$ ethanol immediately after removal and sent to Murdoch University for species identification and molecular analyses. Twenty-six male and 71 female B. concolor ticks were identified based on morphological assessment according to the standard keys for identifying Australian ticks [53].

\section{DNA extraction}

Prior to DNA extraction, ticks were surface-sterilised with $10 \%$ sodium hypochlorite and washed with sterile and DNA-free water, and $70 \%$ ethanol. The extractions were carried out as described by Gofton et al. [52]. 
Negative controls were treated in an identical manner. Borrelia afzelii and B. burgdorferi (s.s.) DNA previously extracted from questing nymphal I. ricinus ticks (LN1, LN6, LN7 and LN9) from Leipzig, Germany [52], were used as positive controls in all PCR assays. DNA from one Borrelia sp.-infected female I. holocyclus tick (NL230) described in Gofton et al. [52], collected from an echidna host in New South Wales was also reanalysed in the present study.

\section{Borrelia-specific PCR and sequencing}

To determine the presence of Borrelia sp. within the 97 B. concolor ticks, and one I. holocyclus tick, DNA extractions were subjected to two Borrelia genusspecific PCR assays. Borrelia-specific nested-PCR assays were conducted targeting the $16 \mathrm{~S}$ rRNA (16S) and flaB genes (Table 1). Each $25 \mu \mathrm{l}$ PCR reaction contained $1 \times$ PerfectTaq buffer, $2.5 \mathrm{mM} \mathrm{MgCl}, 1 \mathrm{mM}$ dNTPs, $400 \mathrm{nM}$ of each primer, $1.25 \mathrm{U}$ PerfectTaq polymerase, and $2 \mu \mathrm{l}$ undiluted DNA. Both the primary and nested Borrelia 16S PCR assays were performed with the following thermal conditions: initial denaturation at $95{ }^{\circ} \mathrm{C}$ for $5 \mathrm{~min}, 35$ cycles of denaturation at $95{ }^{\circ} \mathrm{C}$ for $30 \mathrm{~s}$, annealing at $51{ }^{\circ} \mathrm{C}$ for $40 \mathrm{~s}$, and extension at $72{ }^{\circ} \mathrm{C}$ for $2 \mathrm{~min}$, and a final extension at $72{ }^{\circ} \mathrm{C}$ for $5 \mathrm{~min}$. The flaB PCR assays were performed with an initial denaturation at $95^{\circ} \mathrm{C}$ for $5 \mathrm{~min}, 35$ cycles of denaturation at $95{ }^{\circ} \mathrm{C}$ for $30 \mathrm{~s}$, annealing at $52{ }^{\circ} \mathrm{C}$ (primary) or $55{ }^{\circ} \mathrm{C}$ (nested) for $30 \mathrm{~s}$, and extension at $72{ }^{\circ} \mathrm{C}$ for $30 \mathrm{~s}$, and a final extension at $72{ }^{\circ} \mathrm{C}$ for $5 \mathrm{~min}$. No-template controls and positive controls were included in all PCR assays.

Amplified PCR products were electrophoresed through 1-2 \% agarose gels, stained with GelRed (Biotium), and visualised under UV light. Amplicons of expected sizes were excised from the gel and purified with the Wizard ${ }^{\circ}$ SV Gel and PCR Clean-Up System (Promega Madison,
WI, USA,), according to the manufacturer's recommendations. Purified PCR products were sequenced with both forward and reverse nested PCR primers using BigDye v3.1 terminator on an ABI 373096 Capillary Sequencer (Life Technologies, USA).

\section{Sequence analysis}

Trimmed 16S sequences (1097 bp) generated in this study, together with sequences from other Borrelia spp. retrieved from GenBank, were aligned using MAFFT v7.017 [54], and the alignment was refined using MUSCLE [55]. Spirochaeta americana ASpG1 strain (AF373921) [56] was used as an outgroup. Following multiple sequence alignments, MEGA version 6 [57] was used to determine the most suitable nucleotide substitution model based on the Bayesian Information Criterion (BIC). General time reversible (GTR) model was selected and the Borrelia $16 \mathrm{~S}$ phylogenetic tree was generated using FastTree 2 [58], with 20 rate categories of site and resampling 1000 times. 16S sequences generated in this study were deposited in GenBank under accessions KU954112 to KU954115, and flaB sequences were deposited in GenBank under the accession KX192143 to KX192150.

\section{Results}

\section{Molecular and phylogenetic analyses}

A partial fragment $(407 \mathrm{bp})$ of the Borrelia flaB gene was successfully amplified in three male and 35 female B. concolor ticks $(38 / 97,39 \%)$ and also in the single $I$. holocyclus tick from the previous study [52] (Table 2). All ticks $(n=4)$ from Victoria were negative for Borrelia spp. Bothriocroton concolor ticks that were Borrelia-positive originated from Queensland and New South Wales (38/93, 41 \%) (Additional file 1: Table S1). BLAST analysis showed that, with $100 \%$ query coverage, these

Table 1 Primers used for Borrelia-specific 16S rRNA and flaB genes amplification in this study, including primer sequences, annealing temperature and expected product size

\begin{tabular}{|c|c|c|c|c|c|}
\hline Gene & Primer & Sequence $\left(5^{\prime}-3^{\prime}\right)$ & Annealing temperature & Expected product size (bp) & Reference \\
\hline \multirow[t]{6}{*}{165} & External & & & & \\
\hline & Bor-16 F & TGCGTCTTAAGCATGCAAGT & & & \\
\hline & Bor-1360R & GTACAAGGCCCGAGAACGTA & $51^{\circ} \mathrm{C}$ & 1,344 & This study \\
\hline & Internal & & & & \\
\hline & Bor-27 F & CATGCAAGTCAAACGGAATG & & & \\
\hline & Bor-1232R & ACTGTTCGCTTCGCTITGT & $51^{\circ} \mathrm{C}$ & 1,205 & This study \\
\hline \multirow[t]{6}{*}{$f l a B$} & External & & & & \\
\hline & FlaB280F & GCAGTTCARTCAGGTAACGG & & & \\
\hline & FlaRL & GCAATCATAGCCATTGCAGATTGT & $52^{\circ} \mathrm{C}$ & 645 & {$[33,66]$} \\
\hline & Internal & & & & \\
\hline & flaB_737F & GCATCAACTGTRGTTGTAACATTAACAGG & & & \\
\hline & FlaLL & ACATATTCAGATGCAGACAGAGGT & $55^{\circ} \mathrm{C}$ & 407 & {$[33,66]$} \\
\hline
\end{tabular}


Table 2 Summary of the sex and life stages of the tick specimens used in this study, including the positive controls Ixodes holocyclus and I. ricinus. The geographical regions where the ticks were collected either from a host or vegetation were recorded and the number of ticks positive for Borrelia genes is presented in terms of percentage

\begin{tabular}{|c|c|c|c|c|c|}
\hline \multirow[t]{2}{*}{ Ticks } & \multirow[t]{2}{*}{ Region } & \multirow[t]{2}{*}{ Host/questing } & \multirow[t]{2}{*}{$n$} & \multicolumn{2}{|c|}{$\begin{array}{l}\text { Gene } \\
\text { (\% of positive samples) }\end{array}$} \\
\hline & & & & $16 S$ & $f l a B$ \\
\hline \multicolumn{6}{|c|}{$\begin{array}{l}\text { B. } \\
\text { concolor }\end{array}$} \\
\hline \multirow[t]{3}{*}{ M } & QLD & Echidna & 12 & 0 & 16.6 \\
\hline & NSW & Echidna & 10 & 10 & 10 \\
\hline & VIC & Echidna & 4 & 0 & 0 \\
\hline \multirow[t]{2}{*}{$\mathrm{F}$} & QLD & Echidna & 69 & 36.2 & 50.7 \\
\hline & NSW & Echidna & 2 & 100 & 100 \\
\hline \multicolumn{6}{|c|}{ holocyclus } \\
\hline $\mathrm{F}$ & NSW & Echidna & 1 & 100 & 100 \\
\hline \multicolumn{6}{|c|}{ I. ricinus } \\
\hline $\mathrm{N}$ & $\begin{array}{l}\text { Leipzig, } \\
\text { Germany }\end{array}$ & Questing & 4 & 100 & 100 \\
\hline
\end{tabular}

Abbreviations: $M$ male adult, $F$ female adult, $N$ nymph, QLD Queensland, NSW New South Wales, VIC Victoria

flaB equences shared 87.4-88.6 \% similarity with flaB sequences from B. turcica (GenBank: AB109245; AB109244; AB109241) [41, 42], and with 85.5-86.4\% similarity with B. hermsii (GenBank: AY597795; AY597798) [59]. BLAST analysis of the positive samples isolated from I. ricinus ticks revealed $100 \%$ identity with the LB spirochaetes, with samples LN1, LN7 and LN9 identical to $B$. afzelii at the flaB locus (GenBank: GU826786) [60]; and LN6 identical to B. burgdorferi (GenBank: DQ016620; AF386506; AB035618) [61, 62].

The Borrelia-specific 16S PCR assay was positive for one male and 27 female B. concolor ticks (28/97; $29 \%$ ), all of which were also positive at the flaB locus (Table 2). Three distinct Borrelia $16 \mathrm{~S}$ sequences were produced from $B$. concolor ticks, which differed by only a single nucleotide polymorphism (SNP) $(99.9 \%$ similarity) between the isolates. Alignment with the Borrelia sequence isolated from an I. holocyclus tick, from the previous study [52], revealed that the sequences shared > $99 \%$ identity, with one verified SNP. The three unique Borrelia $16 \mathrm{~S}$ sequences from B. concolor ticks were putatively designated Borrelia sp. Aus A, Borrelia sp. Aus B, and Borrelia sp. Aus C, which occurred in 22, five, and one sample, respectively. The Borrelia $16 \mathrm{~S}$ sequence from the I. holocyclus tick was putatively designated Borrelia sp. NL230.

Phylogenetic analysis indicates that Borrelia $16 \mathrm{~S}$ sequences from this study form a unique monophyletic clade, with high confidence, and that is most similar to, but distinct from the RF and REP Borrelia groups (Fig. 1). Borrelia 16S sequences from these echidna ticks were most dissimilar to the LB group (96.1-96.7 \% similarity); and most similar (98.6-98.7\%) to both Borrelia sp. tAG66M and B. hermsii DAH (Additional file 2: Table S2). Borrelia $16 \mathrm{~S}$ sequences generated from nymphal $I$. ricinus ticks clustered within the B. burgdorferi (s.l.) group, with high (99.9-100 \%) similarity to B. burgdorferi and B. afzelii (Fig. 1).

\section{Discussion}

This study presents the first molecular characterisation in Australia of a novel Borrelia sp. identified in B. concolor (this study) and in a single I. holocyclus tick [52], with a close relationship to the RF and REP-associated Borrelia groups. The current investigation aimed to provide further evidence for Borrelia in echidna ticks, if any, and to validate the previous findings [52] with an increased sample size and by targeting the highly conserved Borrelia housekeeping genes (e.g. flaB and $16 \mathrm{~S}$ rRNA).

The reduced sensitivity of detecting Borrelia with the $16 \mathrm{~S}$ PCR assay, compared to the flaB PCR assay, may be explained by the reduced PCR efficiency that is typically observed when amplifying longer gene fragments. For this reason, PCR assays targeting short gene fragments, such as the $f l a B$ assay used in the present study, are recommended for sensitive detection of Borrelia spp. However, short gene fragments are often inadequate to produce meaningful phylogenetic reconstructions, and therefore must be complimented by assays that amplify longer gene sequences, albeit with less sensitivity, such as the $16 \mathrm{~S}$ assay in the present study.

Recently, REP-associated Borrelia spp. isolated from reptile ticks, $H$. aegyptium, were shown to form a monophyletic clade [42], while sharing a common ancestor with the RF and LB Borrelia groups, supporting the notion of a third Borrelia group [43]. Likewise, the Borrelia sp. identified in this study also forms a unique monophyletic clade, and may form a fourth major phylogenetic Borrelia group. However, further analyses of other Borrelia housekeeping genes, such as $g y r B$, groEL, glpQ genes, and 23S-16S intergenic spacer region [43], and morphological characterisation are necessary for a complete description of this novel Borrelia sp.

The current investigation has provided new records of a Borrelia sp. found in a native Australian hard tick, $B$. concolor $[44,45,52]$. Currently, the degree of similarity and differences between the Borrelia sp. characterised in the present study and B. queenslandica, identified in long-haired rats, R. villosissimus [48], is unknown as molecular data does not exist for this species.

All ticks removed from echidna hosts for the present study were $B$. concolor, a known specialist tick species 


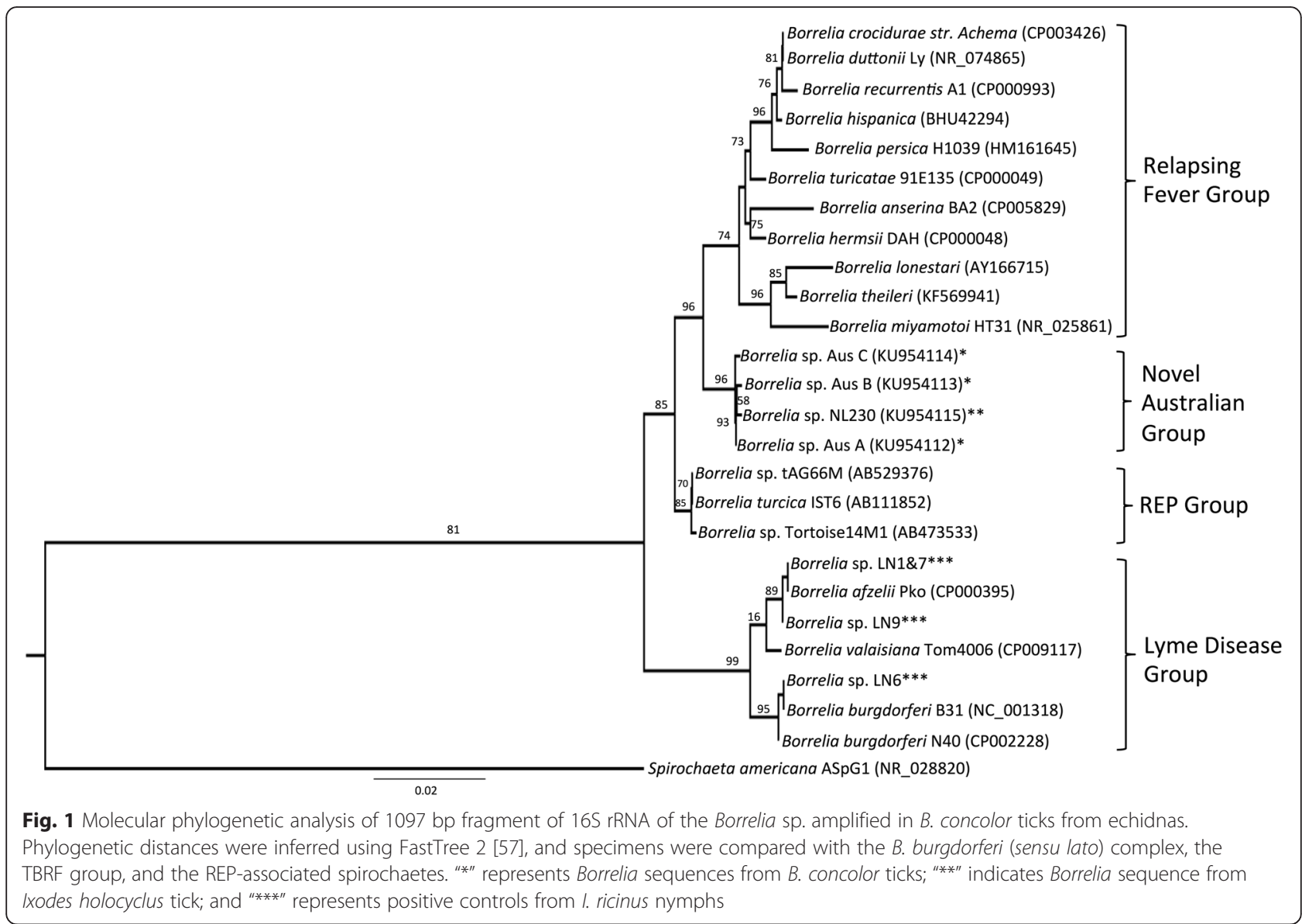

usually restricted to parasitising echidnas (family Tachyglossidae) [53, 63]; however, kangaroos (Macropus fuliginosus fuliginosus) were recently recorded as a new host of B. concolor on Kangaroo Island, South Australia [64]. Bothriocroton concolor has a relatively wide distribution including both coastal and sub-coastal regions of Queensland and New South Wales, as well as inland New South Wales; whereas the distribution of $I$. holocyclus (the host of the first isolate reported by Gofton et al. [52]) is mainly restricted to coastal regions of the eastern Australia [53]. It has been reported that echidnas can also host other tick species such as Amblyomma australiense, Amblyomma echidnae, Amblyomma moyi, Amblyomma papuanum, Bothriocroton tachyglossi, Bothriocroton undatum, Haemaphysalis humerosa and I. tasmani [53]. Therefore, different tick species that feed on the same host may become infected through blood meals, if the echidna serves as a bacteraemic vertebrate reservoir for this bacterium.

Generally, many tick-borne microorganisms circulate within unique sylvatic cycles in an ecosystem, and wildlife and their ticks play important roles as reservoirs and bridging vectors, respectively [65]. In Australia, wildlife and their ticks have long been considered as reservoirs for a number of tick-borne pathogens $[10,16]$. In the case of the vector of Borrelia in Australia, the soft tick, O. gurneyi from long-haired rats, was proposed as a vector of $B$. queenslandica, however, transmission attempts were unsuccessful [48]. Here in the present study, a novel bacterium harboured within $B$. concolor was identified in two tick genera, suggesting that echidnas may be a potential reservoir of this bacterium. However, whether these ticks are able to acquire this bacterium from infected echidna hosts remains to be confirmed through the analysis of echidna blood samples, and until further studies are completed, the vertebrate reservoir of this spirochaete remains to be determined. Likewise, the role of B. concolor and I. holocyclus ticks as potential bridging vectors of this novel Borrelia sp. remains to be assessed via transmission studies. Despite this, the potential and importance of wildlife and their ticks acting as reservoir and vector in maintaining the persistence of this bacterium in the environment cannot be disregarded. The pathogenic consequences (if any) and potential infectivity of this Borrelia sp. to animals and humans are unknown at the present time. 


\section{Conclusions}

The current study has identified a novel Borrelia sp. harboured within echidna ticks. Phylogenetic analysis of the partial $16 \mathrm{~S}$ sequences showed that this Borrelia forms a unique monophyletic clade that is closely related to the RF and REP Borrelia groups and is most dissimilar to the LB group. Moreover, this study highlights the significance of studying Australian wildlife ticks. The presence of a novel Borrelia sp. in Australia is of significant public health importance and warrants further investigations to better understand the biology, ecology, pathogenicity (if any), and infectivity of this organism to humans, domestic animals, and wildlife.

\section{Additional file}

Additional file 1: Table S1. Summary of echidna hosts, clinic, region, number and sex of ticks used in this study, and the number of positive amplifications at each gene. (PDF $165 \mathrm{~kb}$ )

Additional file 2: Table S2. $16 \mathrm{~S}$ rRNA genetic distance matrix showing percentage nucleotide sequence identity between Borrelia sp. from this study and other Borrelia spp., with the outgroup, Spirochaeta americana. (PDF $165 \mathrm{~kb})$

\section{Abbreviations}

16S, $16 \mathrm{~S}$ rRNA; BIC, bayesian information criterion; GTR, general time reversible; LB, Lyme Borreliosis; NSW, New South Wales; QLD, Queensland; REP, reptile-associated; RF, relapsing fever; s.l., sensu lato; s.S., sensu stricto; SNP, single nucleotide polymorphism; TBD, tick-borne disease; TBRF, tick-borne relapsing fever; VIC, Victoria

\begin{abstract}
Acknowledgements
The authors wish to acknowledge the assistance of Reinhard Straubinger and Martin Pfeffer for the collection of Ixodes ricinus ticks in Germany. The authors acknowledge the clinicians and volunteers as well as individuals who have participated in the collection and submission of the tick samples from the Australian Zoo Wildlife Hospital and Wild Days Wildlife shelter. Many thanks to Frances Brigg and the Western Australia State Agricultural Biotechnology Centre for Sanger Sequencing, and Kevin Stratford and the Pawsey Supercomputing Centre for technical assistance during data analysis.
\end{abstract}

\section{Funding}

This study was part-funded by the Australian Research Council (LP13010005), Bayer HealthCare (Germany) and Bayer Australia and is gratefully acknowledged.

\section{Availability of data and materials}

Nucleotide sequences reported in this study were deposited in GenBank under accessions KU954112 to KU954115 and KX192143 to KX192150.

\section{Authors' contributions \\ SL performed tick identification, DNA extractions, PCR assays, data analyses, wrote the manuscript, and participated in the design of the study. AWG designed the primers, performed PCR assays on the Borrelia sp. NL230 isolate, and contributed to data analysis and manuscript preparation. NL contributed to the tick collection and identification, DNA extraction, and preparation of manuscript. AG contributed to tick samples collection and manuscript preparation. UMR and PJI contributed to the design of the study and manuscript preparation. CLO conceived, designed, coordinated the study, and contributed to the data analyses and the preparation of the manuscript. All authors read and approved the final version of the manuscript.}

\section{Competing interests}

The authors declare that they have no competing interests.

\section{Consent for publication}

Not applicable.

\section{Ethics approval and consent to participate}

This study was conducted under the compliance of the Australian Code for the Responsible Conduct of Research, 2007 and Australian Code for the Care and Use of Animals for Scientific Purposes, 2013. Tick collection was carried out opportunistically with approval from the Murdoch University Animal Ethics Committee.

\section{Author details}

${ }^{1}$ Vector and Water-Borne Pathogen Research Laboratory, School of Veterinary and Life Sciences, Murdoch University, Perth, Western Australia, Australia. ${ }^{2}$ School of Biological Sciences, The University of Sydney, Sydney, New South Wales, Australia. ${ }^{3}$ Australia Zoo Wildlife Hospital, Beerwah, Queensland, Australia.

Received: 5 April 2016 Accepted: 7 June 2016

Published online: 14 June 2016

\section{References}

1. Parola P, Raoult D. Ticks and tickborne bacterial diseases in humans: An emerging infectious threat. Clin Infect Dis. 2001;32:897-928.

2. Stuen S, Granquist EG, Silaghi C. Anaplasma phagocytophilum-a widespread multi-host pathogen with highly adaptive strategies. Front Cell Infect Microbiol. 2013;3:31.

3. Dantas-Torres F, Chomel BB, Otranto D. Ticks and tick-borne diseases: a One Health perspective. Trends Parasitol. 2012;28:437-46.

4. Yabsley MJ. Natural history of Ehrlichia chaffeensis: vertebrate hosts and tick vectors from the United States and evidence for endemic transmission in other countries. Vet Parasitol. 2010;167:136-48.

5. Petersen JM, Mead PS, Schriefer ME. Francisella tularensis: an arthropod-borne pathogen. Vet Res. 2009;40:7.

6. Parola P, Paddock CD, Raoult D. Tick-borne rickettsioses around the world: Emerging diseases challenging old concepts. Clin Microbiol Rev. 2005:18:719-56.

7. Barker SC, Walker AR. Ticks of Australia. The species that infest domestic animals and humans. Zootaxa. 2014;3816:1-144.

8. Barker SC, Walker AR, Campelo D. A list of the 70 species of Australian ticks; diagnostic guides to and species accounts of Ixodes holocyclus (paralysis tick), Ixodes cornuatus (southern paralysis tick) and Rhipicephalus australis (Australian cattle tick); and consideration of the place of Australia in the evolution of ticks with comments on four controversial ideas. Int J Parasitol. 2014:44:941-53.

9. Sexton DJ, Dwyer B, Kemp R, Graves S. Spotted fever group rickettsial infections in Australia. Rev Infect Dis. 1991;13:876-86.

10. Stenos J, Graves S, Popov VL, Walker DH. Aponomma hydrosauri, the reptile-associated tick reservoir of Rickettsia honei on Flinders Island, Australia. Am J Trop Med Hyg. 2003;69:314-7.

11. Graves S, Stenos J. Rickettsioses in Australia. Ann N Y Acad Sci. 2009;1166:151-5.

12. Campbell RW, Domrow R. Rickettsioses in Australia: Isolation of Rickettsia tsutsugamushi and R. australis from naturally infected arthropods. Trans Roy Soc Trop Med Hyg. 1974;68:397-402.

13. Bennett MD, Woolford L, Banazis MJ, O'Hara AJ, Warren KS, Nicholls PK, et al Coxiella burnetii in western barred bandicoots (Perameles bougainville) from Bernier and Dorre Islands in Western Australia. EcoHealth. 2011;8:519-24.

14. Smith DJW, Derrick EH. Studies in the epidemiology of Q fever 1. The isolation of six strains of Rickettsia burneti from the tick Haemaphysalis humerosa. Aust J Exp Biol Med Sci. 1940;18:1-8.

15. McDiarmid L, Petney T, Dixon B, Andrews R. Range expansion of the tick Amblyomma triguttatum triguttatum, an Australian vector of $\mathrm{Q}$ fever. Int J Parasitol. 2000;30:791-3.

16. Cooper A, Stephens J, Ketheesan N, Govan B. Detection of Coxiella burnetil DNA in wildlife and ticks in northern Queensland, Australia. Vector Borne Zoonotic Dis. 2013;13:12-6.

17. Tozer SJ, Lambert SB, Strong CL, Field HE, Sloots TP, Nissen MD. Potential animal and environmental sources of $\mathrm{Q}$ fever infection for humans in Queensland. Zoonoses Public Health. 2014;61:105-12. 
18. Banazis MJ, Bestall AS, Reid SA, Fenwick SG. A survey of Western Australian sheep, cattle and kangaroos to determine the prevalence of Coxiella burnetii. Vet Microbiol. 2010;143:337-45.

19. Felsenfeld O. Borreliae, human relapsing fever, and parasite-vector-host relationships. Bacteriol Rev. 1965;29:46-74.

20. Trees AJ. The transmission of Borrelia theileri by Boophilus annulatus (Says, 1821). Trop Anim Health Prod. 1978;10:93-4.

21. Smith RD, Miranpuri GS, Adams JH, Ahrens EH. Borrelia theileri: isolation from ticks (Boophilus microplus) and tick-borne transmission between splenectomized calves. Am J Vet Res. 1985;46:1396-8.

22. Varela-Stokes AS. Transmission of bacterial agents from lone star ticks to white-tailed deer. J Med Entomol. 2007;44:478-83.

23. van Duijvendijk G, Coipan C, Wagemakers A, Fonville M, Ersöz J, Oei A, et al. Larvae of Ixodes ricinus transmit Borrelia afzelii and B. miyamotoi to vertebrate hosts. Parasit Vectors. 2016:9:97.

24. Raoult $D$, Roux $V$. The body louse as a vector of reemerging human diseases. Clin Infect Dis. 1999;29:888-911.

25. Rudenko N, Golovchenko M, Grubhoffer L, Oliver Jr JH. Updates on Borrelia burgdorferi sensu lato complex with respect to public health. Ticks Tick Borne Dis. 2011;2:123-8.

26. Fukunaga M, Okada K, Nakao M, Konishi T, Sato Y. Phylogenetic analysis of Borrelia species based on flagellin gene sequences and its application for molecular typing of Lyme disease borreliae. Int J Syst Bacteriol. 1996:46:898-905

27. Toledo A, Anda P, Escudero R, Larsson C, Bergstrom S, Benach JL. Phylogenetic analysis of a virulent Borrelia species isolated from patients with relapsing fever. J Clin Microbiol. 2010;48:2484-9.

28. Fraenkel CJ, Garpmo U, Berglund J. Determination of novel Borrelia genospecies in Swedish Ixodes ricinus ticks. J Clin Microbiol. 2002;40:3308-12.

29. Fukunaga M, Takahashi Y, Tsuruta Y, Matsushita O, Ralph D, McClelland M, et al. Genetic and phenotypic analysis of Borrelia miyamotoi sp. nov., isolated from the ixodid tick /xodes persulcatus, the vector for Lyme disease in Japan. Int J Syst Bacteriol. 1995;45:804-10.

30. Platonov AE, Karan LS, Kolyasnikova NM, Makhneva NA, Toporkova MG, Maleev W, et al. Humans infected with relapsing fever spirochete Borrelia miyamotoi, Russia. Emerg Infect Dis. 2011;17:1816-23.

31. Mun J, Eisen RJ, Eisen L, Lane RS. Detection of a Borrelia miyamotoi sensu lato relapsing-fever group spirochete from Ixodes pacificus in California. J Med Entomol. 2006;43:120-3.

32. Scoles GA, Papero M, Beati L, Fish D. A relapsing fever group spirochete transmitted by Ixodes scapularis ticks. Vector Borne Zoonotic Dis. 2001;1:21-34.

33. Barbour AG, Maupin GO, Teltow GJ, Carter CJ, Piesman J. Identification of an uncultivable Borrelia species in the hard tick Amblyomma americanum: possible agent of a Lyme disease-like illness. J Infect Dis. 1996;173:403-9.

34. Lin T, Gao L, Seyfang A, Oliver Jr JH. 'Candidatus Borrelia texasensis', from the American dog tick Dermacentor variabilis. Int J Syst Evol Microbiol. 2005;55:685-93.

35. Assous MV, Wilamowski A. Relapsing fever borreliosis in Eurasia-forgotten, but certainly not gone! Clin Microbiol Infec. 2009;15:407-14.

36. Boyer KM, Munford RS, Maupin GO, Pattison CP, Fox MD, Barnes AM, et al. Tick-borne relapsing fever: an interstate outbreak originating at Grand Canyon National Park. Am J Epidemiol. 1977;105:469-79.

37. Schwan TG, Raffel SJ, Schrumpf ME, Webster LS, Marques AR, Spano R, et al. Tick-borne Relapsing Fever and Borrelia hermsii, Los Angeles County, California, USA. Emerg Infect Dis. 2009;15:1026-31.

38. Dupont HT, La Scola B, Williams R, Raoult D. A focus of tick-borne relapsing fever in southern Zaire. Clin Infect Dis. 1997;25:139-44.

39. Trape JF, Diatta G, Arnathau C, Bitam I, Sarih M, Belghyti D, et al. The epidemiology and geographic distribution of relapsing fever borreliosis in West and North Africa, with a review of the Ornithodoros erraticus complex (Acari: Ixodida). PLoS ONE. 2013;8(11):e78473.

40. Vial L, Diatta G, Tall A, el Ba H, Bouganali H, Durand P, et al. Incidence of tick-borne relapsing fever in west Africa: longitudinal study. Lancet. 2006;368:37-43.

41. Guner ES, Hashimoto N, Kadosaka T, Imai Y, Masuzawa T. A novel, fast-growing Borrelia sp. isolated from the hard tick Hyalomma aegyptium in Turkey. Microbiology. 2003;149:2539-44.

42. Guner ES, Watanabe M, Hashimoto N, Kadosaka T, Kawamura Y, Ezaki T, et al. Borrelia turcica sp. nov., isolated from the hard tick Hyalomma aegyptium in Turkey. Int J Syst Evol Microbiol. 2004;54:1649-52.
43. Takano A, Goka K, Une Y, Shimada Y, Fujita H, Shiino T, et al. Isolation and characterization of a novel Borrelia group of tick-borne borreliae from imported reptiles and their associated ticks. Environ Microbiol. 2010;12:134-46.

44. Callow LL, Hoyte HMD. Transmission experiments using Babesia bigemina, Theileria mutans, Borrelia sp. and the cattle tick. Aust Vet J. 1961:37:381-90.

45. Mulhearn CR. A note on two blood parasites of cattle (Spirochaeta theileri and Bartonella bovis) recorded for the first time in Australia. Aust Vet J. 1946:22:118.

46. Gorrie CJR. Vaccination against spirochetosis in fowls. Aust Vet J. 1950;26:308-15.

47. Petney TN, Andrews RH, McDiarmid LA, Dixon BR. Argas persicus sensu stricto does occur in Australia. Parasitol Res. 2004;93:296-9.

48. Carley JG, Pope JH. A new species of Borrelia (B. queenslandica) from Rattus villosissimus in Queensland. Aust J Exp Biol Med Sci. 1962:40:255-61.

49. Mackerras MJ. The haematozoa of Australian mammals. Aust J Zool. 1959;7:105-35.

50. Wills MC, Barry RD. Detecting the cause of Lyme disease in Australia. Med J Aust. 1991;155:275.

51. Augee M, Gooden B, Musser A. Echidna: extraordinary egg-laying mammal. Collingwood: CSIRO Publishing; 2006.

52. Gofton AW, Oskam CL, Lo N, Beninati T, Wei H, McCarl V, et al. Inhibition of the endosymbiont "Candidatus Midichloria mitochondrii" during 165 rRNA gene profiling reveals potential pathogens in Ixodes ticks from Australia. Parasit Vectors. 2015;8:345

53. Roberts FHS. Australian ticks. 2nd ed. Melbourne: CSIRO; 1970.

54. Katoh K, Misawa K, Kuma K, Miyata T. MAFFT: a novel method for rapid multiple sequence alignment based on fast Fourier transform. Nucleic Acids Res. 2002;30:3059-66.

55. Edgar RC. MUSCLE: multiple sequence alignment with high accuracy and high throughput. Nucleic Acids Res. 2004;32:1792-7.

56. Hoover RB, Pikuta EV, Bej AK, Marsic D, Whitman WB, Tang J, et al. Spirochaeta americana sp. nov., a new haloalkaliphilic, obligately anaerobic spirochaete isolated from soda Mono Lake in California. Int J Syst Evol Microbiol. 2003;53:815-21.

57. Tamura K, Stecher G, Peterson D, Filipski A, Kumar S. MEGA6: Molecular evolutionary genetic analysis version 6.0. Mol Biol Evol. 2013;30:2725-9.

58. Price MN, Dehal PS, Arkin AP. FastTree 2-approximately maximum-likelihood trees for large alignments. PLoS ONE. 2010;5:e9490.

59. Porcella SF, Raffel SJ, Anderson Jr DE, Gilk SD, Bono JL, Schrumpf ME, et al. Variable tick protein in two genomic groups of the relapsing fever spirochete Borrelia hermsii in western North America. Infect Immun 2005;73:6647-58.

60. Reye AL, Hubschen JM, Sausy A, Muller CP. Prevalence and seasonality of tick-borne pathogens in questing Ixodes ricinus ticks from Luxembourg. Appl Environ Microbiol. 2010;76:2923-31.

61. Wodecka B. flaB gene as a molecular marker for distinct identification of Borrelia species in environmental samples by the PCR-restriction fragment length polymorphism method. Appl Environ Microbiol. 2011;77:7088-92.

62. Quessada T, Martial-Convert F, Arnaud S, Leudet De La Vallee H, Gilot B, et al. Prevalence of Borrelia burgdorferi species and identification of Borrelia valaisiana in questing Ixodes ricinus in the Lyon region of France as determined by polymerase chain reaction-restriction fragment length polymorphism. Eur J Clin Microbiol Infect Dis. 2003;22:165-73.

63. Belan I, Bull CM. Host-seeking behaviour by Australian ticks (Acari: Ixodidae) with differing host specificities. Exp Appl Acarol. 1995;19:221-32.

64. Oorebeek M, Rismiller P. Bothriocroton concolor (Acari: Ixodidae) on the Kangaroo Island kangaroo: a new host-parasite relationship. J Med Entomol. 2007:44:901-2.

65. Hamer SA, Hickling GJ, Keith R, Sidge JL, Walker ED, Tsao Jl. Associations of passerine birds, rabbits, and ticks with Borrelia miyamotoi and Borrelia andersonii in Michigan, U.S.A. Parasit Vectors. 2012;5:231.

66. Clark KL, Leydet B, Hartman S. Lyme borreliosis in human patients in Florida and Georgia, USA. Int J Med Sci. 2013;10:915-31. 